\title{
Coastal Boulders on the SE Coasts of Cyprus as Evidence of Palaeo-Tsunami Events
}

\author{
Niki Evelpidou 1,*(D), Christos Zerefos ${ }^{1,2,3}$, Costas Synolakis ${ }^{3,4,5}$, Christos Repapis ${ }^{2}$, \\ Anna Karkani ${ }^{1}$ (D), Miltiadis Polidorou ${ }^{1}$ and Giannis Saitis ${ }^{1}$ (D) \\ 1 Faculty of Geology and Geoenvironment, National and Kapodistrian University of Athens, \\ Panepistimiopolis, 15774 Athens, Greece; zerefos@geol.uoa.gr (C.Z.); ekarkani@geol.uoa.gr (A.K.); \\ mpolidorou@geol.uoa.gr (M.P.); saitij@geol.uoa.gr (G.S.) \\ 2 Mariolopoulos-Kanaginis Foundation for Environmental Sciences, 30-32 Patriarchou Ioakim Str., \\ 10675 Athens, Greece; repapis@mariolopoulosfoundation.gr \\ 3 Research Centre for Atmospheric Physics and Climatology, Academy of Athens, 84 Solonos str., \\ 10680 Athens, Greece; costas@usc.edu \\ 4 Department of Environmental Engineering, Technical University of Crete, Polytechnioupoli, \\ 73100 Chanea, Greece \\ 5 Department of Civil and Environmental Engineering, University of Southern California, \\ Los Angeles, CA 90089-2531, USA \\ * Correspondence: evelpidou@geol.uoa.gr
}

Received: 3 September 2020; Accepted: 15 October 2020; Published: 19 October 2020

\begin{abstract}
Cyprus has a long history of tsunami events, as noted by archaeological and geological records. At Cape Greco (southeastern Cyprus) large boulders have been noted, however, no detailed geomorphological research has taken place so far and the related high energy event was undated until now. Our research aims to record in detail and interpret these large boulders deposits. The boulders, located between $\approx 3$ and $4.5 \mathrm{~m}$ a.m.s.l., are fragments of an upper Pleistocene aeolianite, which is overlaying unconformly a lower Pleistocene calcarenite. Dimensions and spatial distribution of 272 small, medium, and large boulders were documented, while their precise distance from the coastline was recorded by field mapping and remote sensing, using Differential GPS (DGPS), drone, and Geographic Information Systems (GIS) technics. Field data were subsequently combined with hydrodynamic equations, in order to determine the extreme event(s) that caused their transport inland, and radiocarbon dating was accomplished on three samples of Vermetus sp. to determine the chronological context. Our findings appear to broadly correlate with the 1303 AD tsunami, which has displaced at least part of the studied boulders, and one other undocumented event at AD 1512-1824. The large number of boulders and sizes in our study area further indicate that their dislocation is most likely owed to multiple events from various sources.
\end{abstract}

Keywords: boulders; coastal hazard; palaeo-tsunami; storm; eastern Mediterranean

\section{Introduction}

Large boulder accumulations along the coasts have been widely used in the literature to reconstruct and determine the high energy event that displaced them. Such boulders or mega-blocks are often found isolated or in groups bearing evidence of their transportation from their original location. Characteristics include their placement in altitudes of few meters above mean sea level (a.m.s.l.), individually, or in clusters, with the presence of features that certify their transfer from the intertidal or supratidal zone. Boulder deposits have been linked with storm events [1-4] as well as tsunamis [5-11].

The interpretation of the high energy events, capable of dislocating large boulders, remains controversial [12] and have been interpreted as both "storm" and "tsunami" deposits and they often 
display similar characteristics [13]. The investigation of modern tsunami deposits can provide key features to better distinguish such events [14], such as the 2004 Indian ocean tsunami [7,15], or the 2011 Japan tsunami [16-18]. Landward imbrication has been noted by various researchers from recent tsunami deposits $[17,19]$, although this feature may be also found in storm deposits. According to Etienne and Paris [2] elongated boulders are characterized by their imbrication or long axis being tangent to the tsunami wave train, and thus allow to determine the direction of the wave. Tsunami boulders further do not display a particular trend in size distribution along the flow direction $[18,20]$.

Different hydrodynamic equations $[18,21-24]$ have been developed to decipher the origin of the deposits through the calculation of wave heights and velocities necessary to transport them. The micro-tidal regime and limited fetch in the Mediterranean is ideal for the application of such equations, as maximum possible storm wave heights are smaller in comparison to areas where significant storm wave heights may occur [20]. When the calculated storm wave heights differ greatly from the wave-storm regime of the study area, then a tsunamigenic origin is deduced [6].

Research on palaeo-high energy events is fundamental to understand the coastal responses of tsunami or storm impact, for estimating the impact of past events for coastal hazard mitigation. Cyprus has a large history of seismic wave activity as described by archaeological and geological records. There is abundance of historical records in literature, which are linked to the development of tsunamis in the Eastern Mediterranean $[25,26]$. The presence of various geomorphological evidence indicative of tsunamis has been noted by several researchers $[27,28]$ in various areas in Cyprus (e.g., Kormakitis peninsula, Gialoussa coast, Cape Greco, Ayia Napa, Pafos airport, Kissonergas, Lara and Akamas peninsula) (Figure 1). The most interesting indicators are boulder deposits, which may be found in various locations in Cyprus, primarily on the west and southeast coasts (Figure 1) [27,28]. In this paper, we focus on the boulders found on the coastal zone of Cape Greco. Their presence has been previously noted by Whelan and Kelletat [28], estimating a weight of 10-20 tons.

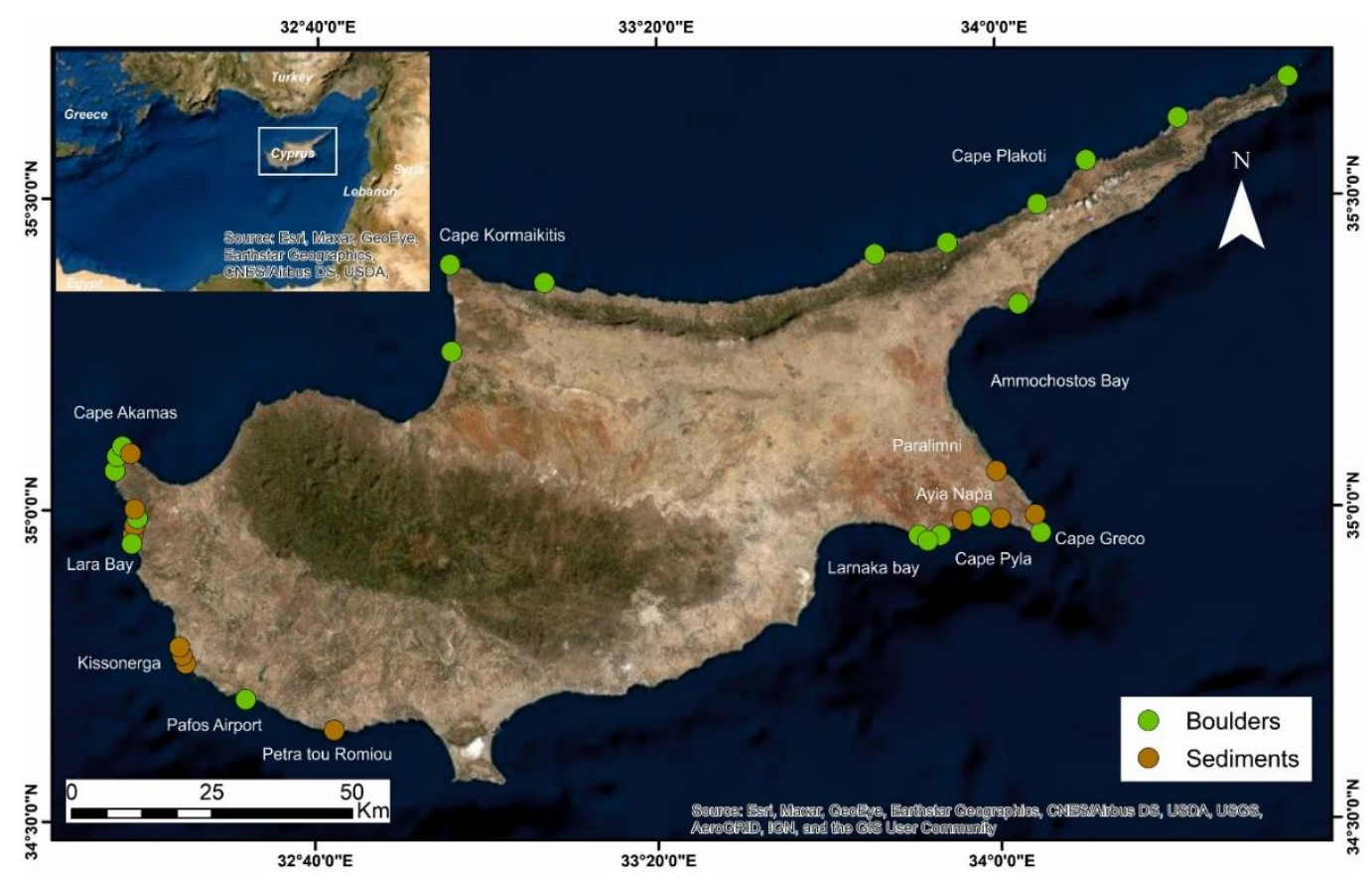

Figure 1. Geomorphological evidence of tsunamis around the coastal zone of Cyprus (data from [27-29]). At the southeastern part is Cape Greco, the study area. Base map sources: Esri, DigitalGlobe, GeoEye, i-cubed, USDA FSA, USGS, AEX, Getmapping, Aerogrid, IGN, IGP, swisstopo, and the GIS User Community. 
The aim of our paper is to demonstrate that the boulders on the coastal zone of Cape Greco were transported and deposited by tsunamis and to provide a chronological framework, in order to correlate them with known earthquakes and tsunamis in the wider area.

\section{Study Area}

\subsection{Geological Setting}

The island of Cyprus is located in the south east part of the Mediterranean Sea. The morphology of the southern coast of Cyprus is complex, being partly a result of Miocene-Quaternary tectonic uplift reaching $5 \mathrm{~m} / \mathrm{ka}$ [30]. A relatively simple straight coastline profile is observed southwest of Larnaca Bay. This simple morphology changes gradually into a rocky, tectonically uplifted shoreline with several bays and pools towards the east. The presence of a low-lying rocky shoreline continues through Cape Greco until the shores of Ammochostos Bay [31].

Our study area, Cape Greco, lies at the south-eastern part of the island and forms a narrow peninsula between Ayia Napa and Paralimni area (Figure 1). It mainly consists of Pliocene marls of the Nicosia Formation and Miocene Terra reefal limestone sandshales, part of the Pakhna Formation [32]. These formations are overlain by calcarenites and beachrocks, which are abundant in Pleistocene terrace deposits [31]. The studied boulders are located on an almost horizontal rocky platform of Pleistocene calcarenites, at a mean altitude of $\approx 3 \mathrm{~m}$ (Figures 2 and 3 ).

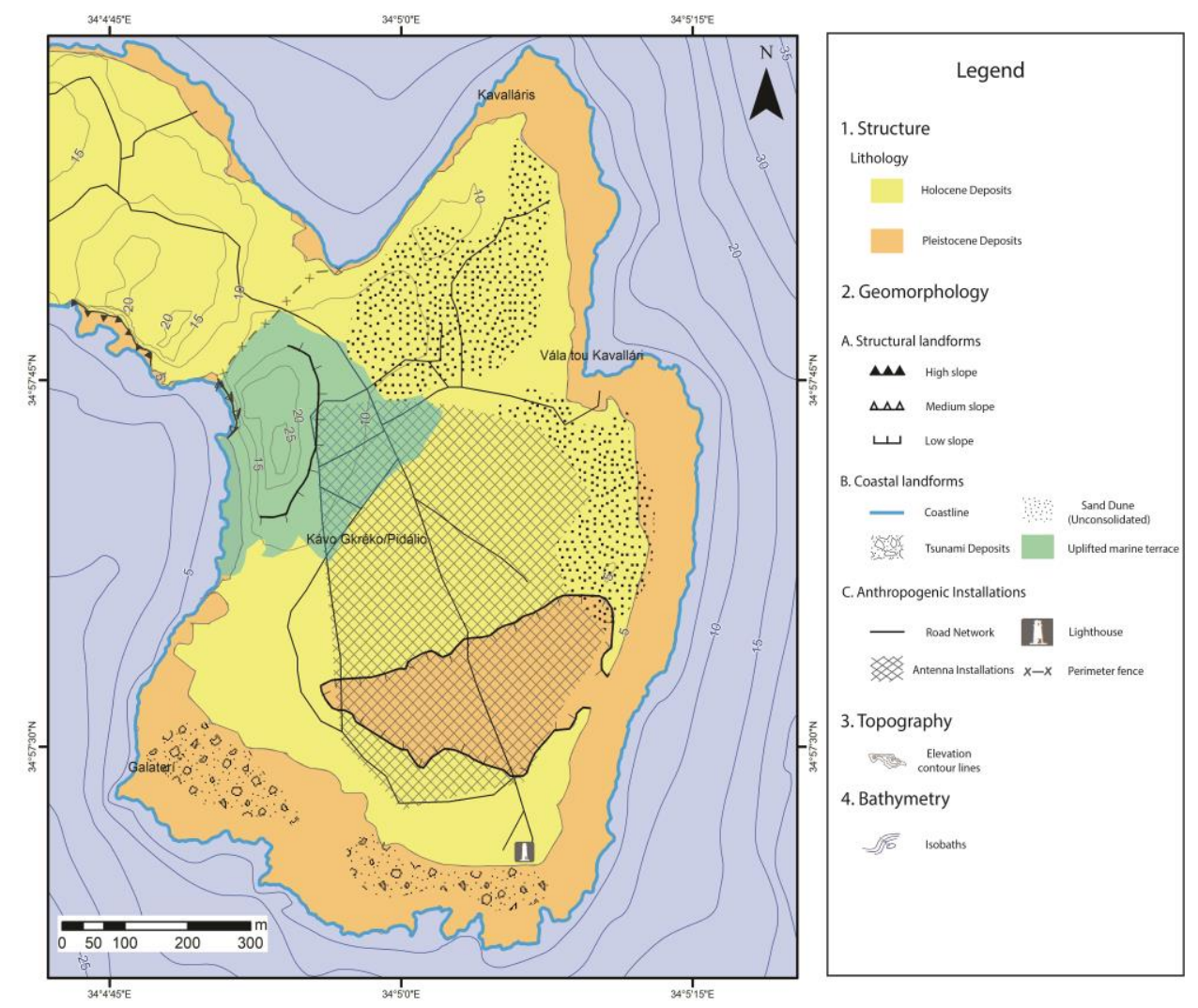

Figure 2. Geomorphological map of Cape Greco. 


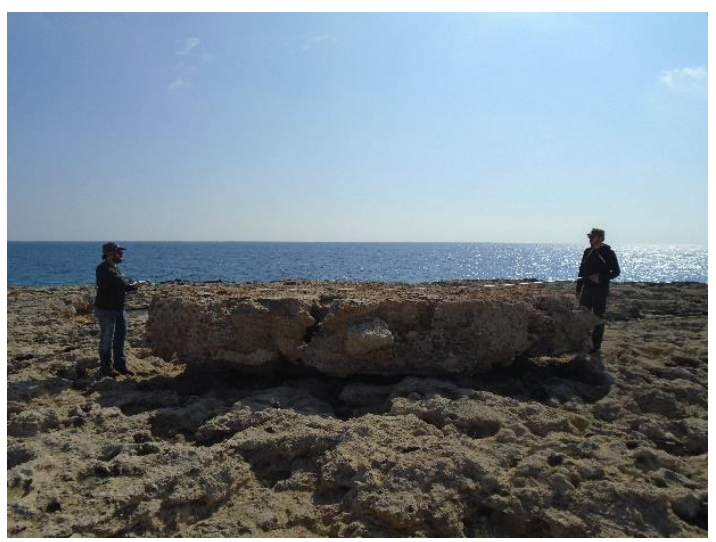

(a)

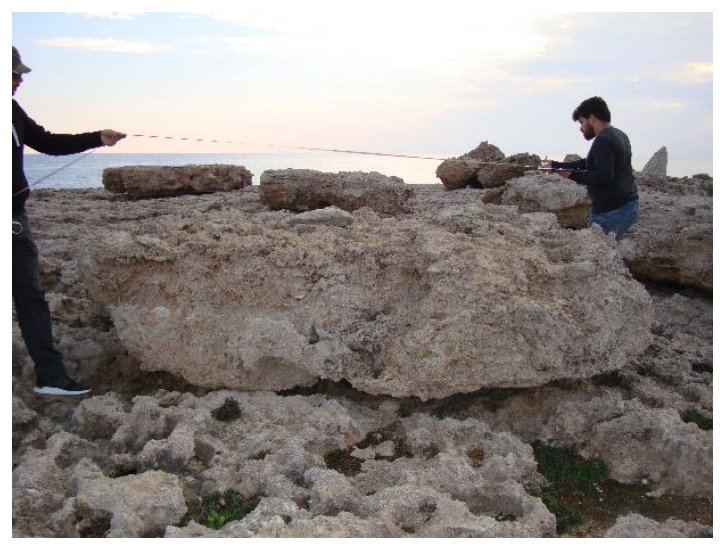

(c)

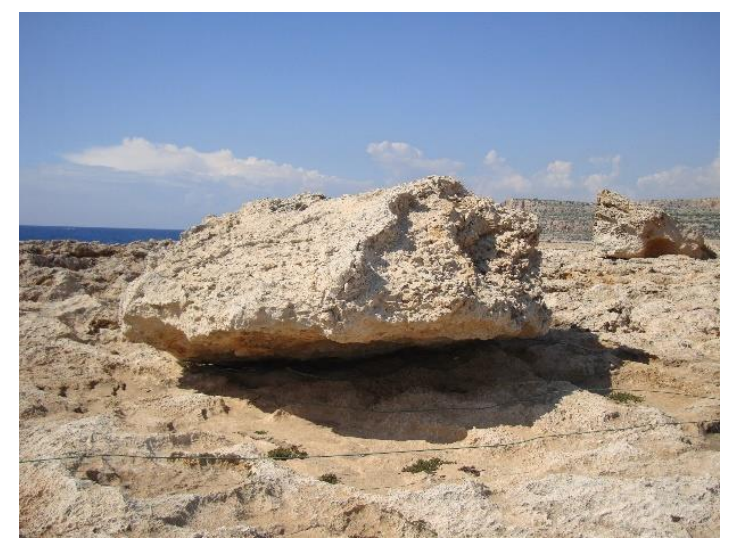

(b)

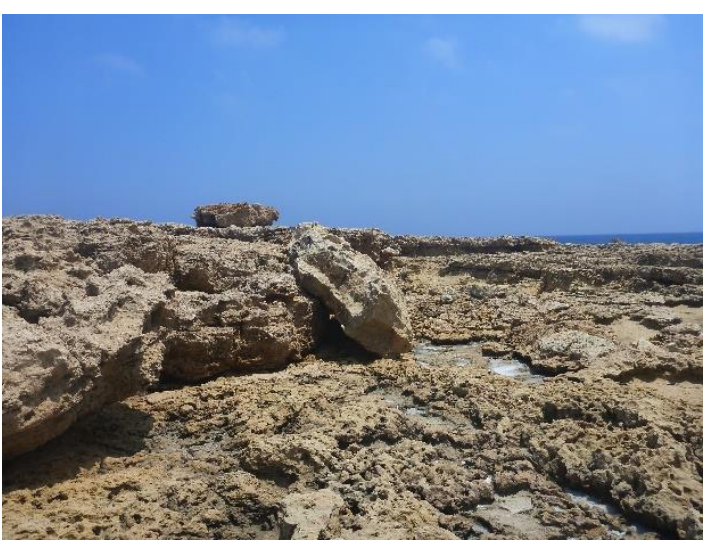

(d)

Figure 3. Characteristic boulder deposits from the study area at Cape Greco. (a, b) Two of the largest boulders in the study area; the boulder of (a) is also visible in the background of (c) and (d).

\subsection{Seismicity}

The easternmost part of the Mediterranean Sea is seismotectonically dominated by the Cyprean arc and the left-lateral strike-slip Levantine rift (Figure 4). In the Cyprean arc shallow- and intermediate-depth earthquakes occur mostly in the submarine environment and, therefore, high-magnitude shocks are expected to generate strong tsunamis [25].

In Cyprus an association between tsunami events and earthquakes has been documented through history [33-36] as well as in archaeological [37,38], historical [39,40], and geomorphological studies [28,41] (Table 1 ).

The spatial distribution of tsunami events in the Cyprus-Levantine Sea region is not random and relates to the tectonic setting of the wider region. According to Fokaefs and Papadopoulos [25], they are concentrated along two zones: (a) Zone of south Cyprus, where earthquake activity follows the south part of Cyprus along the Cyprean arc and the seismogenic sources under the sea favors the generation of tsunamis by co-seismic fault dislocations and (b) Levantine Sea from Gaza northward zone in which causative earthquakes are mainly associated with the left-lateral strike-slip fault system of the Levantine rift, which implies that the seismogenic sources are not located in a submarine environment but on land and, therefore, the tsunami generation mechanism remains unexplained. 


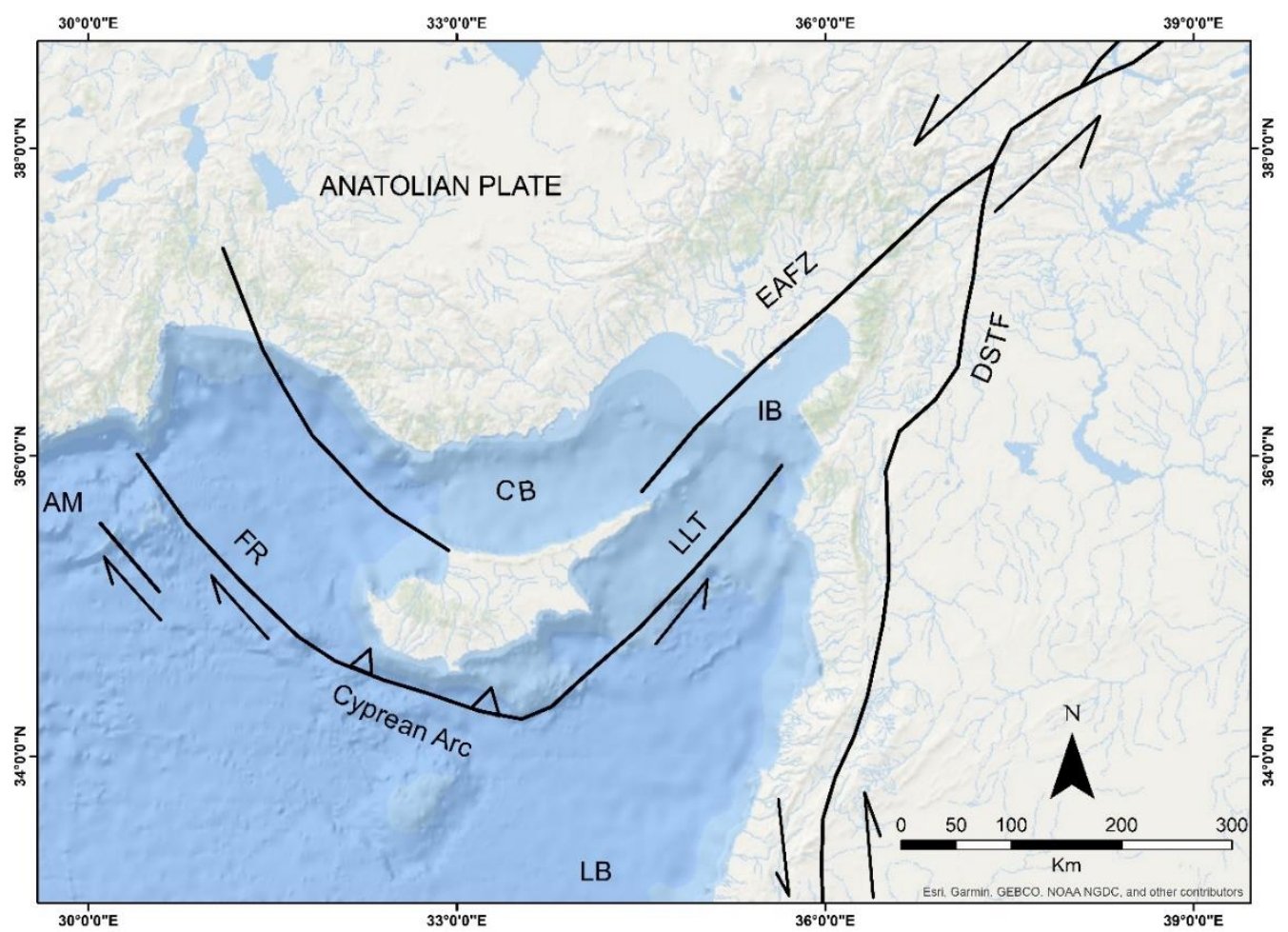

Figure 4. Simplified tectonic framework of the study area, within the eastern Mediterranean, where AM is the Anaximader Mountains, CB is Cilica Basin, DSFZ the Dead Sea Transform Fault Zone, FR the Florence Rise, EAFZ the East Anatolian Fault Zone, IB Iskenderun Bay, LLT Latakia-Larnaka-Tartus ridges, LB Levantine Basin (adapted from [33]).

Table 1. The most important earthquakes and tsunamis to have affected Cyprus since 1200 AD [25,42,43].

\begin{tabular}{|c|c|c|c|c|}
\hline Date & Source & Area Affected & Description & Reference \\
\hline 1202 & $\begin{array}{l}\text { Possibly landslide } \\
\text { near the Levantine } \\
\text { coast due to a strong } \\
\text { earthquake }\end{array}$ & $\begin{array}{l}\text { Levantine coast } \\
\text { and Cyprus }\end{array}$ & $\begin{array}{l}\text { The sea between Cyprus and } \\
\text { the Levantine coast parted and } \\
\text { mountainous waves piled up } \\
\text { throwing ships onto the land. Eastern } \\
\text { parts of the island were flooded. }\end{array}$ & [34] \\
\hline 1222 & $\begin{array}{l}\text { Strong submarine } \\
\text { earthquake south of } \\
\text { Pafos }\end{array}$ & Cyprus & $\begin{array}{l}\text { Earthquake destruction and } \\
\text { destructive tsunami flooding in Pafos } \\
\text { and Lemesos. The castle of Pafos } \\
\text { collapsed and the harbor was left } \\
\text { without water. }\end{array}$ & [25] \\
\hline 1303 & $\begin{array}{l}\text { Strong earthquake in } \\
\text { Hellenic Arc between } \\
\text { Crete and Rhodes }\end{array}$ & $\begin{array}{l}\text { From Crete to } \\
\text { Levantine } \\
\text { coasts }\end{array}$ & $\begin{array}{l}\text { Destructive tsunami in Crete. } \\
\text { Damaging sea-wave in Rhodes. } \\
\text { Tsunami reported to be seen at SW } \\
\text { Turkey, Egypt, Cyprus, and Palestine. }\end{array}$ & [43] \\
\hline 1953 & $\begin{array}{l}\text { Strong double } \\
\text { earthquake } \\
\text { south-west of Cyprus }\end{array}$ & Cyprus & $\begin{array}{l}\text { Destructive tsunami in Crete. } \\
\text { Damaging sea-wave in Rhodes. } \\
\text { Tsunami reported to be seen at SW } \\
\text { Turkey, Egypt, Cyprus, and Palestine. } \\
\text { Small tsunami along the coast of Pafos } \\
\text { which caused no damage. }\end{array}$ & [25] \\
\hline
\end{tabular}

\subsection{Significant Wave Height}

Wave heights in Cyprus waters are generally lower than in the large ocean basins because of generally weaker storms. Published data for the period 1961-1980 from ship observations near Cape 
Greco suggests average significant wave heights between 0.25 and $0.75 \mathrm{~m}$ [44]. According to the same dataset, extreme wave heights with a modelled 100-years return period reach 4.7-5 m, with SSE to SSW direction [44]. Buoy data for the period between July 2005 to February 2008 at an open ocean sea point west of the Eratosthenes Seamount suggest significant wave heights less than $1.5 \mathrm{~m}$, with a frequency percentage of $\approx 94 \%$ [45]. The highest recorded value is 4.75 , with a frequency percentage of $0.0167 \%$ for the same time period.

\section{Materials and Methods}

\subsection{Fieldwork}

A geomorphological survey was conducted along the coastal zone of Cape Greco (Figures 2 and 3). Detailed mapping of the boulders was realized in the field using a hand-held GPS and DGPS-GNSS system for their precise location. Topographic profiles were performed perpendicular to the coast, using DGPS-GNSS (Figure 5). The measurement of all boulder dimensions was realized using a measuring tape, i.e., a-b-c axis (length-width-height). The a-axis direction was also recorded, their elevation from sea level $(\mathrm{m})$, and their distance from the coastline. Aerial photography was accomplished using a DJI mavic pro drone. An orthomosaic was developed using Agisoft PhotoScan by combining 840 aerial photographs taken from the drone.

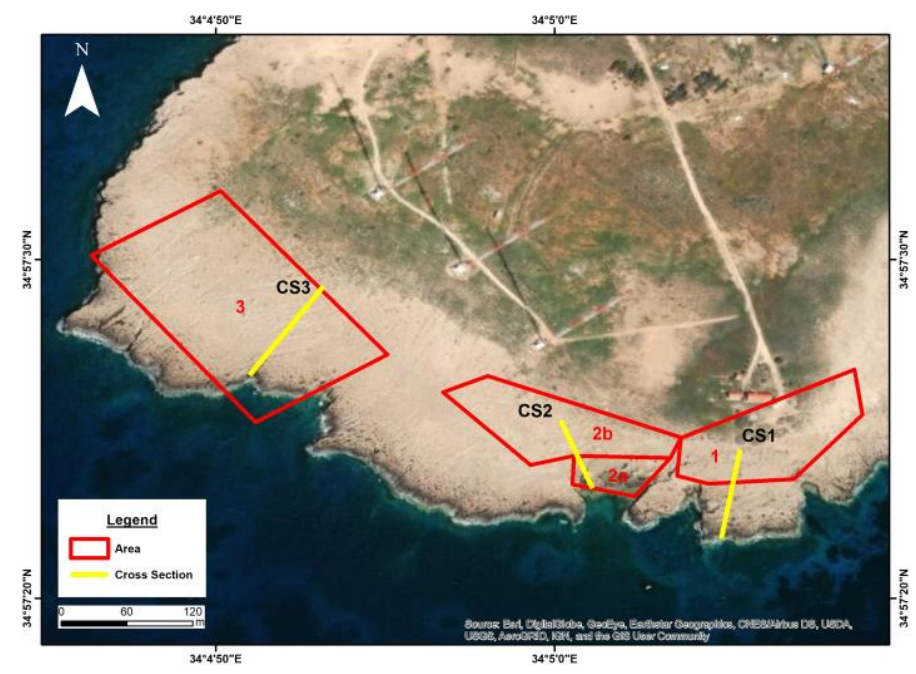

Figure 5. The investigated area at Cape Greco, the locations of the three cross-sections, and the division into four subareas, which are further discussed in the text. Base map sources: Esri, DigitalGlobe, GeoEye, i-cubed, USDA FSA, USGS, AEX, Getmapping, Aerogrid, IGN, IGP, swisstopo, and the GIS User Community.

\subsection{Radiocarbon Dating}

A thorough field investigation was accomplished in order to locate fossils (for ${ }^{14} \mathrm{C}$ dating) that may reflect when the boulders were transported. Marine fossils that may reflect when the boulders were transported are very rare in the study area, and the investigated boulders are composed of calcarenite. Nevertheless, three samples of marine gastropods (Vermetus sp.) were collected from the studied boulders for radiocarbon dating. These marine gastropods suggest an offshore to inland transportation during the dislocation of the boulders from their in-situ position and, therefore, they may constrain the age of the high energy events.

Radiocarbon dating was carried out at CEntro di DAtazione e Diagnostica (CEDAD), in Lecce, Italy, on three samples of Vermetus sp. Radiocarbon ages were calibrated through the online software Calib 7.10 [46], with the Marine13 curve. The samples were corrected for the local marine reservoir effect using a mean $\Delta \mathrm{R}$ value of $53 \pm 43$ for the Eastern Mediterranean [47]. 


\subsection{Estimation of Boulder Weight and Volume}

For the determination of the boulders' mass $(\mathrm{M})$, volume $(\mathrm{V})$, and density $(\rho b)$, we used the water displacement method, in the laboratory, in two samples collected from the calcarenite and the subaerially-eroded red horizon, respectively. The data from the two samples were combined with the measurements of the three major axes to determine the weight of the boulders. For the calculation of the boulders volume, the maximum length of a-, b-, and c-axes, i.e., length, width, and height, respectively, was used: $\mathrm{V}=\mathrm{a} \times \mathrm{b} \times \mathrm{c}$.

\subsection{Hydrodynamic Equations}

A numerical approach was used to quantify the wave height (storm or tsunami) necessary for the detachment and transportation of the boulders inland. The hydrodynamic equations for storm and tsunamis and the boulder transportation scenarios were initially derived by Nott [21]. The developed hydrodynamic equations are covering a part of all likely scenarios for boulder transportation. The scenarios relate to the possible original position of the boulder. Thus, the main scenarios are focusing on a possible submerged boulder prior to transportation called the "submerged boulder (SMB) scenario". A subaerial boulder scenario (SAB) is considered for cases when the boulders are moved by waves on shore. Finally, a joint bounded block scenario (JBB) was taken into account in order to include a possible movement of boulders that were dislocated from the rocky coast or for boulders that resulted from a rock fall on a sea-cliff. For our case study we focused on the hydrodynamic approach by Pignatelli et al. [22] and Nandasena et al. [48] for the joint-bounded block scenario (JBB) and submerged boulder scenario (SMB). For comparison on the resulting wave height values, other hydrodynamic approaches were considered $[23,24,49]$.

For our calculations, a mean coefficient of drag $\left(C_{d}\right)$ of 1.2 was considered, according to Helley [50] and Benner et al. [23] through a graph based on the shape factor (SF) of the boulders. Furthermore, since the boulders are composed of calcareous material, the coefficient of mass $\left(C_{m}\right)$ was given a value of 2. Additionally, we used a coefficient of lift $\left(\mathrm{C}_{\mathrm{L}}\right)$ of 0.178 according to Noormets et al. [51], coefficient of friction of the boulders $\left(\mu_{\mathrm{s}}\right)$ of 0.65 , the instantaneous flow acceleration of the boulder as $1 \mathrm{~m} \mathrm{~s}^{-2}$ [23], and the sea water density of $1.02 \mathrm{~g} \mathrm{~cm}^{-3}$.

\section{Results}

\subsection{Field Investigation and Boulders Distribution}

During field work, a total number of 272 boulders were identified and studied (Figure 6). The measured density from the two main lithologies in the study area was calculated at $1.94 \times 10^{3} \mathrm{~kg} \mathrm{~m}^{-3}$ for the calcarenite and $1.97 \times 10^{3} \mathrm{~kg} \mathrm{~m}^{-3}$ for subaerially-eroded red horizon. Based on the boulders volume calculations, 154 have sizes less than $2 \mathrm{~m}^{3}, 81$ boulders up to $6 \mathrm{~m}^{3}, 24$ boulders up to $10 \mathrm{~m}^{3}$, and 13 very large boulders over $10 \mathrm{~m}^{3}$ with a remarkable note of the largest up to $41.68 \mathrm{~m}^{3}$ (Figure 6). 


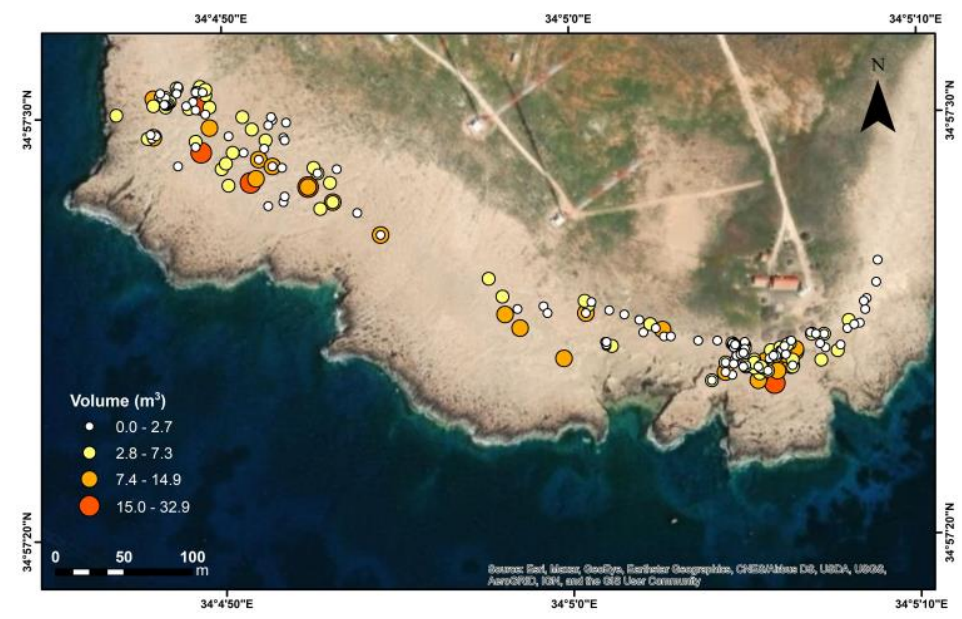

Figure 6. Distribution of studied boulders in the study area, according to their volume $\left(\mathrm{m}^{3}\right)$. Base map sources: Esri, DigitalGlobe, GeoEye, i-cubed, USDA FSA, USGS, AEX, Getmapping, Aerogrid, IGN, IGP, swisstopo, and the GIS User Community.

The vast majority of the boulders are located at an altitude between 3 and $4.6 \mathrm{~m}$ a.m.s.l., with the exception of 10 boulders lying at the erosional platform at about $1 \mathrm{~m}$ elevation (Figures 7 and 8). Their distance from the coastline varies between 5 and $100 \mathrm{~m}$, but most are arranged at a distance of $70 \mathrm{~m}$ from the shoreline (Figures 7 and 8 ). Two main clusters of boulder distribution may be recognized, one at the western part and the second at the eastern part of the study area, while in the central part only few boulders were found sporadically. On the eastern part, a notable accumulation of boulders was in imbricated clusters (Figure 9).
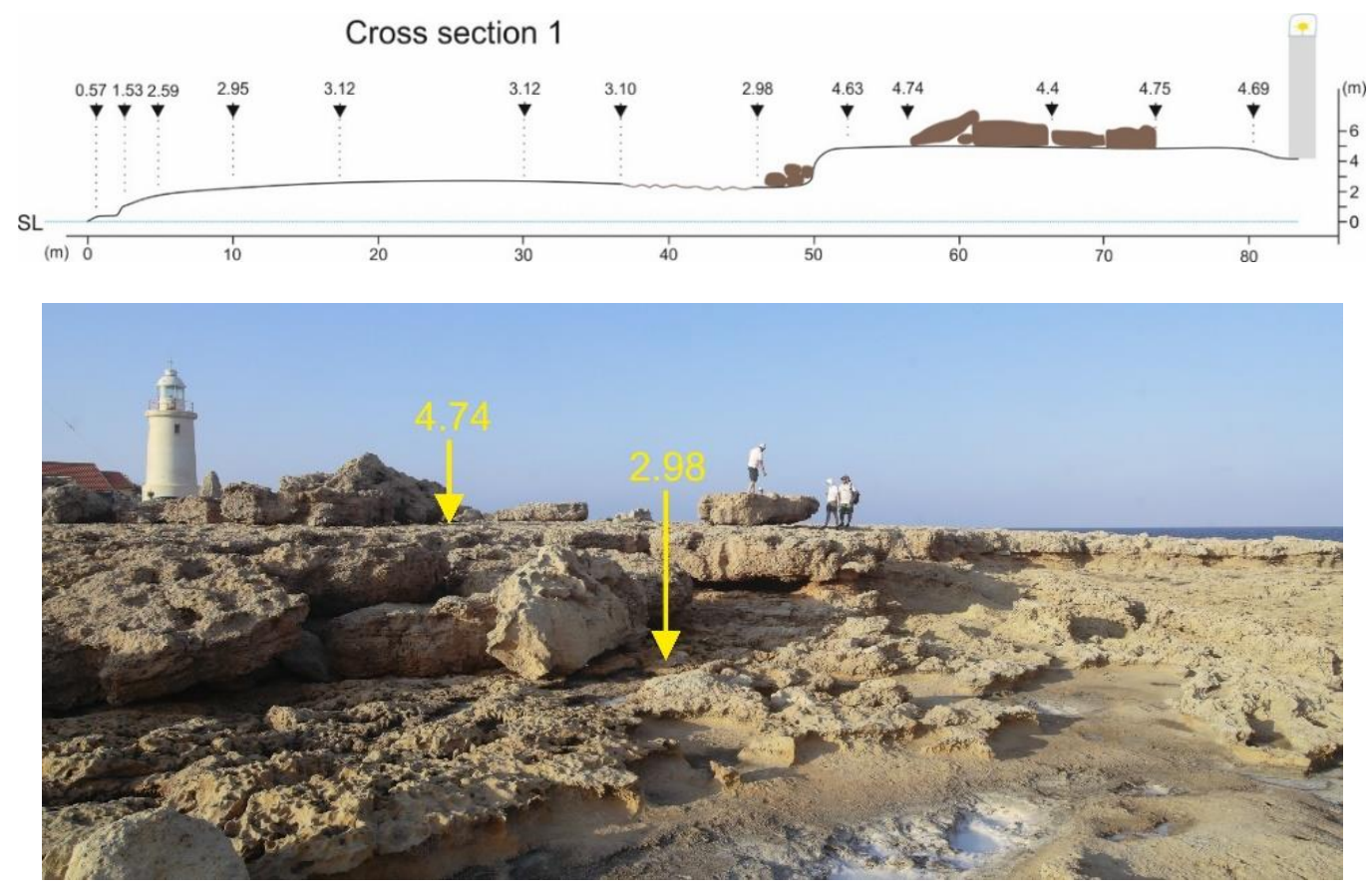

(a)

Figure 7. Cont. 


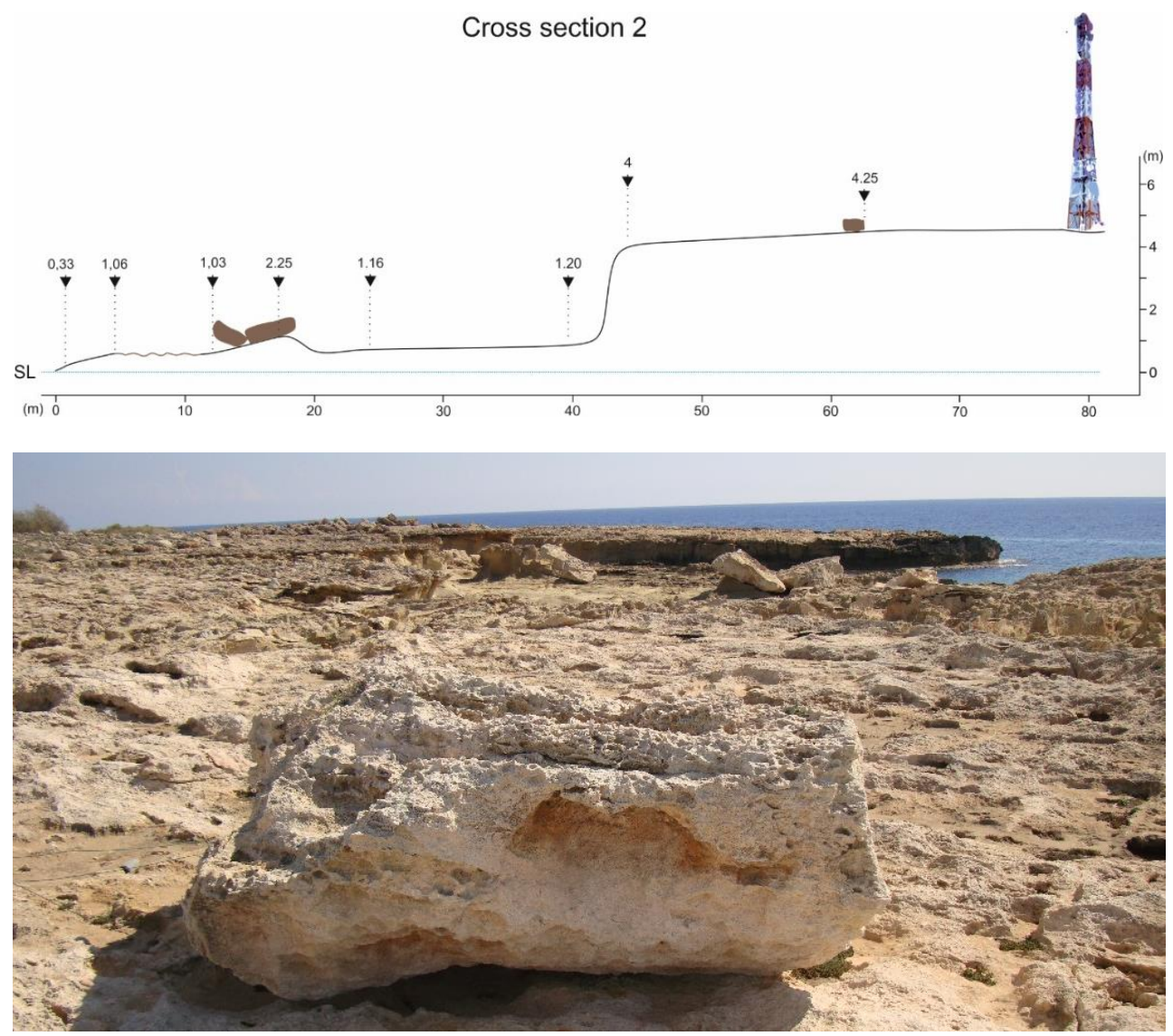

(b)
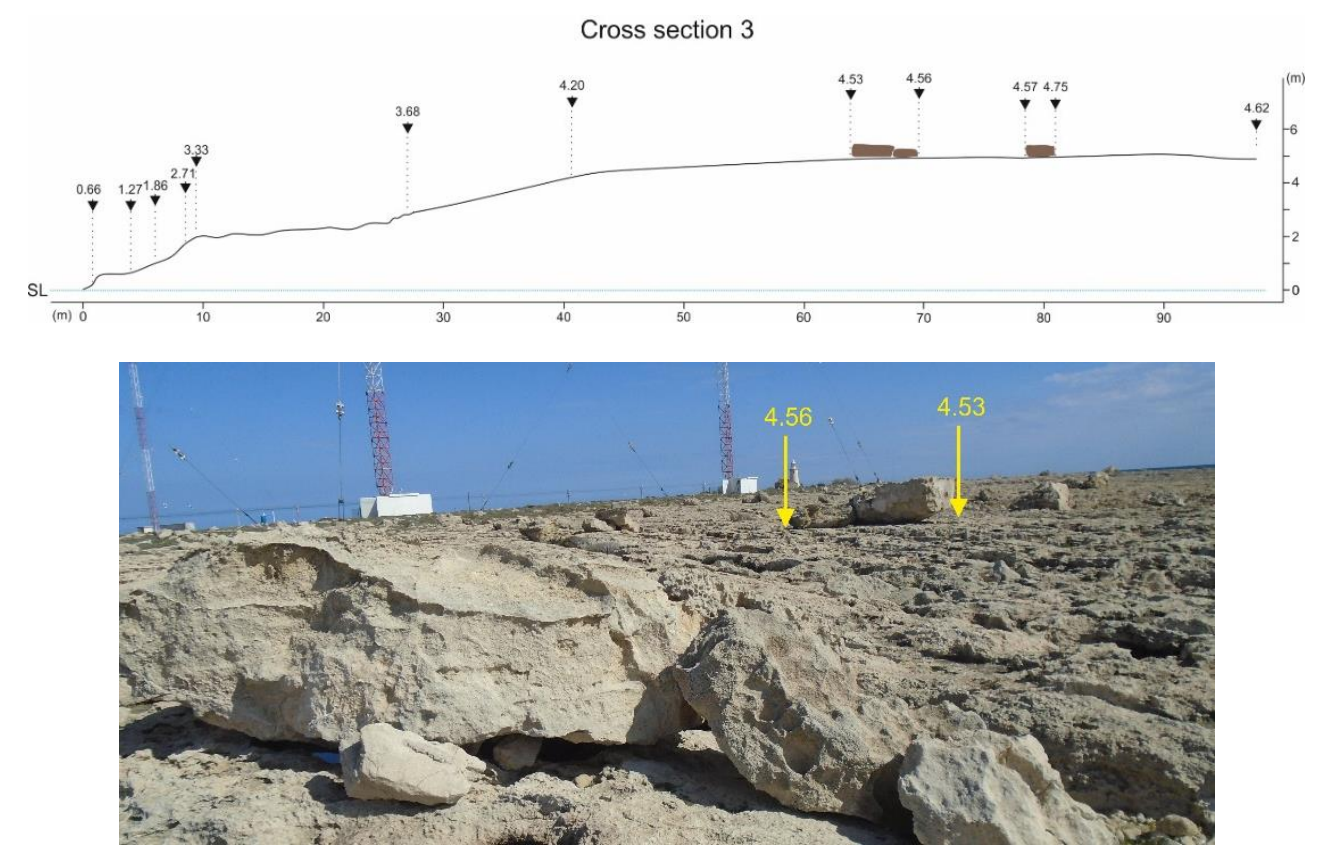

(c)

Figure 7. Topographic sections of the study area (SL is sea level, dashed lines with arrows show the elevation); (a) Cross Section 1 and a corresponding photograph as viewed from the SW; (b) Cross Section 2 and the boulder located at about 4.25 m elevation; (c) Cross Section 3 and a corresponding photograph. The cross-section traces are shown in Figure 5. 


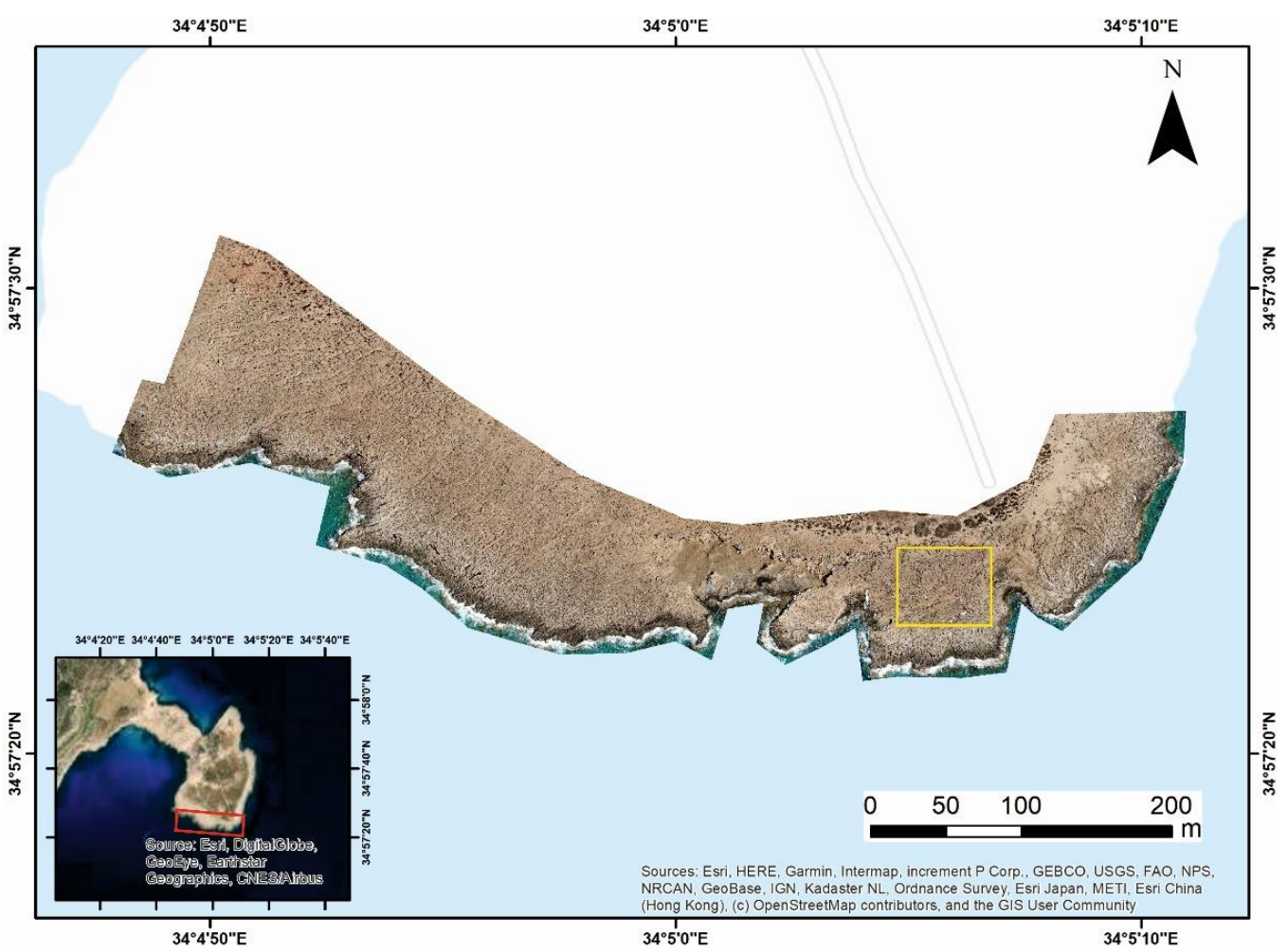

(a)

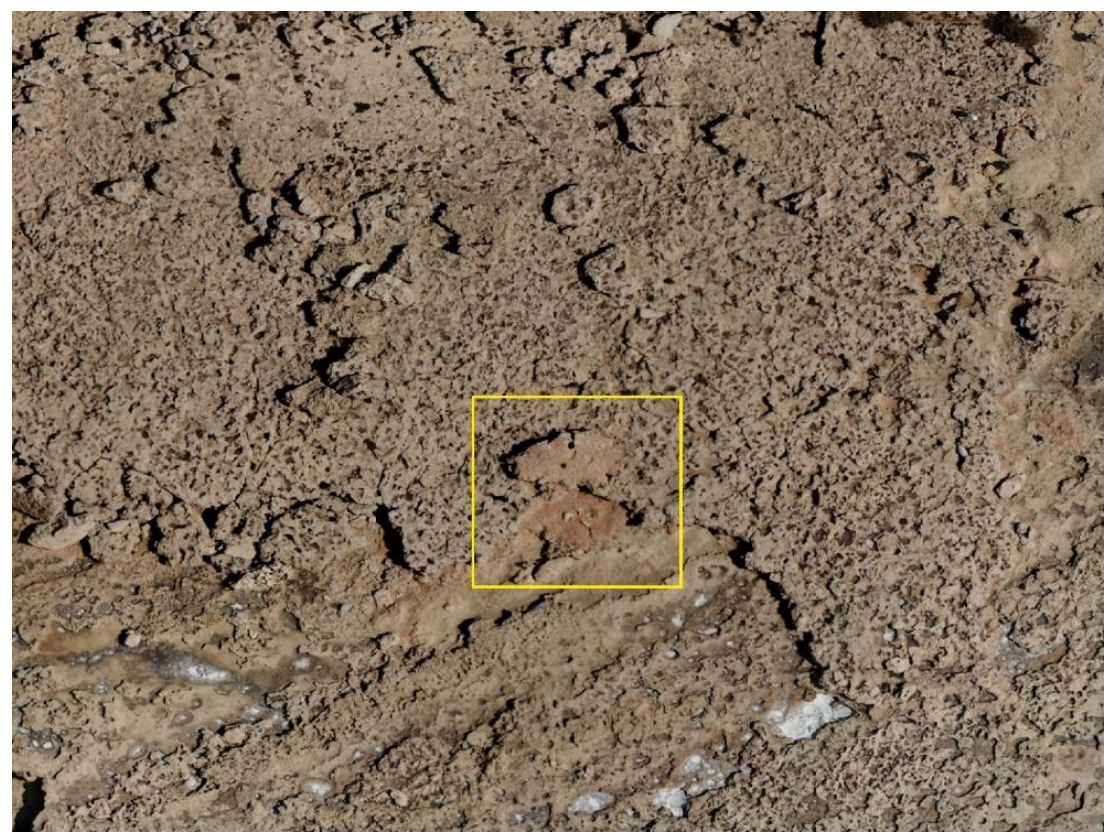

(b)

Figure 8. (a) Orthomosaic of the study area. Base map sources: Esri, DeLorme, HERE, TomTom, Intermap, increment P Corp., GEBCO, USGS, FAO, NPS, NRCAN, GeoBase, IGN, Kadaster NL, Ordnance Survey, Esri Japan, METI, Esri China (Hong Kong), swisstopo, MapmyIndia, and the GIS User Community; (b) a closer view (yellow box in (a)) from the eastern part of the orthomosaic, where in the center (yellow square) a boulder (no 189) is evident that has been turned upside down, and its original location is clearly visible, supporting a joint-bounded scenario. 


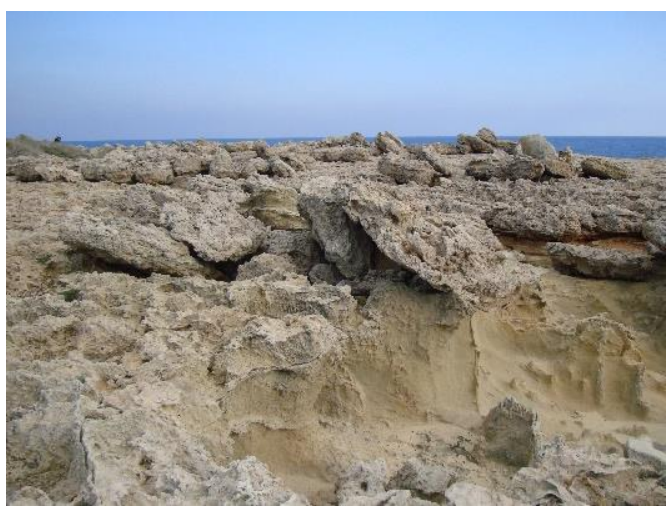

(a)

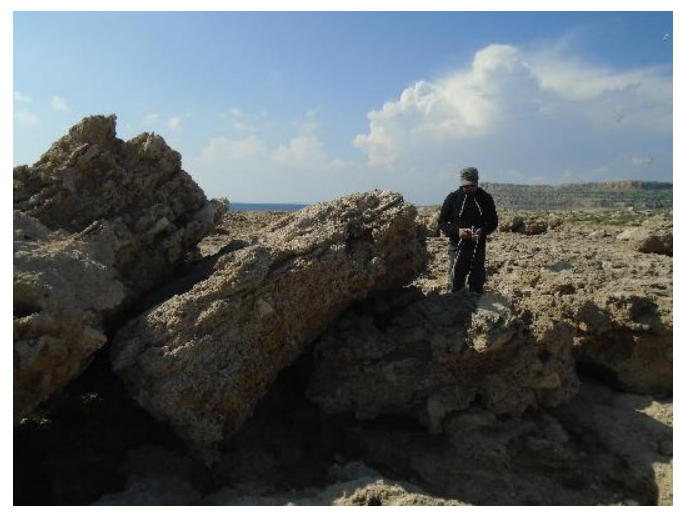

(b)

Figure 9. (a) Clusters of imbricated boulders on the eastern part of the study area; (b) a closer view of imbricated boulders.

\subsection{Wave Height Calculation}

Taking into account the likely boulder transportation scenarios (see Section 3.4) and based on field observations, a scenario of joint-bounded blocks (JBB) was considered for boulders located at areas 1 and $2 b$, while for the boulders of the western part (area 3 ) a scenario of submerged boulder (SMB) was additionally taken in account. Considering the scenario and using the hydrodynamic equations by Pignatelli et al. [22] and Nandasena et al. [48], the wave heights for storm and tsunami capable of transporting boulders, are presented in Table 2. Table 2 further includes calculations derived from Barbano et al. [49], Benner et al. [23], and Engel and May [24], for comparison.

Table 2. Selected boulder measurements and storm wave height calculations based on different hydrodynamic equations [22-24,48,49]. All boulder measurements and calculations are provided in Table S1.

\begin{tabular}{|c|c|c|c|c|c|c|c|c|c|c|}
\hline \multicolumn{9}{|c|}{ Five Largest Values of Storm Wave Height for JBB Scenario } & \multirow{2}{*}{\multicolumn{2}{|c|}{$\begin{array}{c}\text { SAB Scenario } \\
\text { Engel and May } \\
\text { (2012) }\end{array}$}} \\
\hline $\begin{array}{l}\text { Boulder } \\
\text { No }\end{array}$ & \multicolumn{3}{|c|}{ Axes (m) } & \multirow[t]{2}{*}{$\begin{array}{c}\text { Volume } \\
\left(\mathrm{m}^{3}\right)\end{array}$} & \multicolumn{2}{|c|}{$\begin{array}{l}\text { Pignatelli et al. } \\
\text { (2009) }\end{array}$} & \multicolumn{2}{|c|}{$\begin{array}{c}\text { Nandasena et al. } \\
\text { (2011) }\end{array}$} & & \\
\hline & a-axis & b-axis & c-axis & & $\mathbf{H}_{\mathrm{s}}(\mathrm{m})$ & $\mathbf{H}_{\mathrm{t}}(\mathrm{m})$ & $\mathbf{H}_{\mathrm{s}}(\mathrm{m})$ & $\mathrm{H}_{\mathrm{t}}(\mathrm{m})$ & Hs (m) & $\mathrm{Ht}(\mathrm{m})$ \\
\hline 57 & 1.77 & 1.09 & 1.87 & 2.71 & 19.57 & 4.89 & 15.24 & 3.81 & 32.03 & 8.01 \\
\hline 41 & 5.13 & 3.10 & 1.62 & 19.32 & 16.95 & 4.24 & 13.20 & 3.30 & 573.86 & 143.47 \\
\hline 86 & 4.80 & 4.29 & 1.60 & 24.71 & 16.74 & 4.19 & 13.04 & 3.26 & 678.34 & 169.58 \\
\hline 94 & 4.31 & 1.98 & 1.58 & 10.11 & 16.53 & 4.13 & 12.87 & 3.22 & 246.07 & 61.52 \\
\hline 98 & 3.50 & 1.52 & 1.52 & 6.07 & 15.91 & 3.98 & 12.39 & 3.10 & 115.37 & 28.84 \\
\hline \multicolumn{11}{|c|}{ Five Largest Values of Storm Wave Height for SMB Scenario } \\
\hline \multirow[t]{2}{*}{$\begin{array}{c}\text { Boulder } \\
\text { No }\end{array}$} & \multicolumn{3}{|c|}{ Axes (m) } & $\begin{array}{l}\text { Volume } \\
\left(\mathrm{m}^{3}\right)\end{array}$ & \multicolumn{2}{|c|}{$\begin{array}{c}\text { Nandasena et al. } \\
\text { (2011) }\end{array}$} & \multicolumn{2}{|c|}{$\begin{array}{c}\text { Barbano et al. } \\
\text { (2010) }\end{array}$} & \multicolumn{2}{|c|}{$\begin{array}{l}\text { Benner et al. } \\
\text { (2010) }\end{array}$} \\
\hline & a-axis & b-axis & c-axis & & $\mathrm{H}_{\mathrm{s}}(\mathrm{m})$ & $\mathrm{H}_{\mathrm{t}}(\mathrm{m})$ & $\mathrm{H}_{\mathrm{s}}(\mathrm{m})$ & $\mathrm{H}_{\mathrm{t}}(\mathrm{m})$ & $\mathrm{H}_{\mathrm{s}}(\mathrm{m})$ & $\mathrm{H}_{\mathrm{t}}(\mathrm{m})$ \\
\hline 86 & 4.80 & 4.29 & 1.60 & 24.71 & 7.40 & 1.85 & 8.64 & 2.16 & 72.78 & 18.20 \\
\hline 53 & 5.49 & 4.41 & 1.12 & 20.34 & 7.27 & 1.82 & 8.17 & 2.04 & 72.79 & 18.23 \\
\hline 87 & 2.62 & 4.46 & 1.10 & 9.638 & 7.28 & 1.82 & 8.16 & 2.04 & 73.12 & 18.28 \\
\hline 3 & 4.10 & 3.70 & 0.98 & 11.15 & 6.17 & 1.54 & 6.96 & 1.74 & 61.83 & 15.46 \\
\hline 72 & 5.18 & 3.32 & 1.23 & 15.86 & 5.73 & 1.43 & 6.69 & 1.67 & 56.38 & 14.10 \\
\hline
\end{tabular}

According to hydrodynamic equations of Pignatelli et al. [22] for a JBB scenario, the displacement of the largest boulder could have taken place by a minimum storm wave $\left(\mathrm{H}_{\mathrm{S}}\right)$ of $\approx 19.57 \mathrm{~m}$ or a tsunami wave $\left(\mathrm{H}_{\mathrm{t}}\right)$ of $\approx 4.89 \mathrm{~m}$, while according to Nandasena et al. [48] a minimum storm of $\approx 15.24 \mathrm{~m}$ or a tsunami wave of $\approx 3.81 \mathrm{~m}$ would be necessary. In case of the boulders that were submerged at the $t 0$ of 
the wave impact, a boulder of a-axis $230 \mathrm{~cm}$, b-axis $210 \mathrm{~cm}$, and c-axis $80 \mathrm{~cm}$, would need a minimum storm wave $\left(\mathrm{H}_{\mathrm{s}}\right)$ of $\approx 3.6 \mathrm{~m}$ or a tsunami wave $\left(\mathrm{H}_{\mathrm{t}}\right)$ of $\approx 0.90 \mathrm{~m}$. In agreement with Piscitelli et al. [3], the equations by Benner et al. [23] and Engel and May [24] provide very high values.

\subsection{Radiocarbon Results}

Amongst the three dated shell samples, sample LTL19211A was not considered as it provided an age younger than 1950 AD. The calibrated ages of the two other samples (LTL19209A, LTL19210A) are, respectively, 1512-1824 AD and 1309-1496 AD (Table 3).

Table 3. Dating results of shell fragments collected on boulders.

\begin{tabular}{cccccc}
\hline Boulder No & Sample Code & Lab Code & Material & 14C Age (BP) & $\begin{array}{c}\text { Calibrated } \\
\text { Age (BC/AD) }\end{array}$ \\
\hline 6 & ANT001 & LTL19209A & Vermetus sp. & $696 \pm 45 \mathrm{BP}$ & AD 1512-1824 \\
26 & ANT002 & LTL19210A & Vermetus sp. & $987 \pm 45 \mathrm{BP}$ & AD 1309-1496 \\
31 & ANT003 & LTL19211A & Vermetus sp. & $>1950$ AD & - \\
\hline
\end{tabular}

\section{Discussion}

\subsection{Geomorphological Evidence and Boulder Origin}

The geomorphological context of the study area suggests a complex pre-transport location for the studied boulders. Erosional and weathering processes are active in the area, predominantly owed to sea waves and sea spray. On the lower part of the rocky platform, near sea level, a well-developed wave cut notch exists and it appears that the origin of some boulders of area 1 is owed to the collapse and detachment of the notch's roof, due to the force of waves. On the same site (area 1), between the calcarenite and the aeolianite formations (Figure 10a,b), a subaerially-eroded red horizon was identified, which appears to have acted as a detachment zone. This is particularly characteristic on boulder 189, which is evident that has been turned upside down, and its original location is clearly visible (Figure 8 b), supporting a joint-bounded scenario. Some large boulders have irregular shapes and sharp edges, as well as micro-karstic solution on their surface, indicating that they most likely derived from the edge of the rocky platform. Marine bio-constructions are scarce in the studied boulders, which further support a supratidal origin.

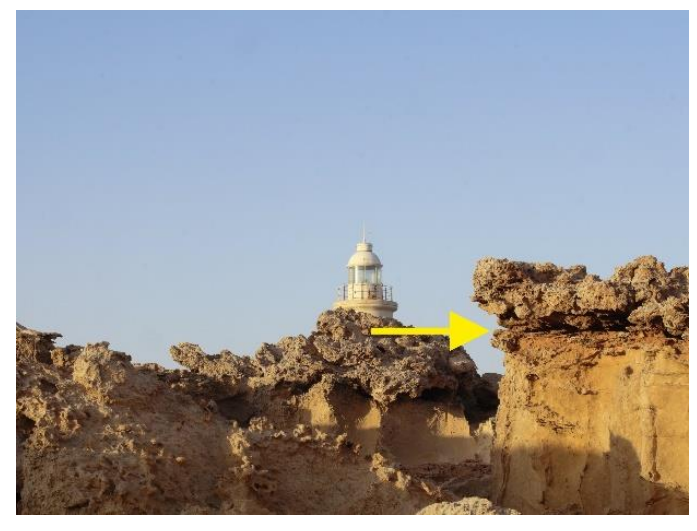

(a)

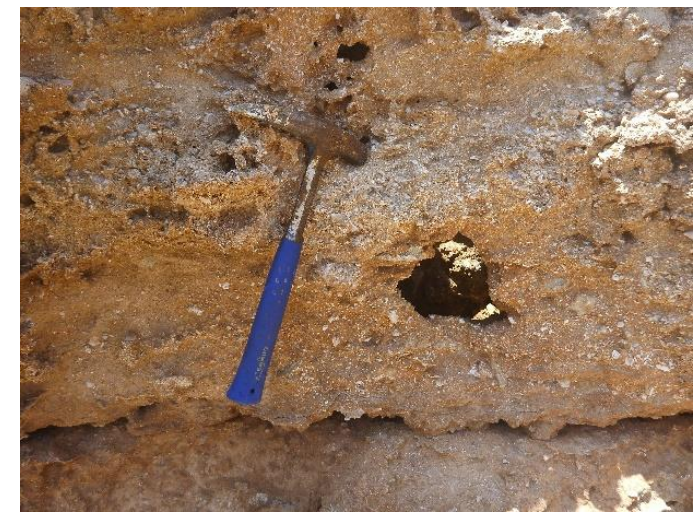

(b)

Figure 10. (a) The subaerially eroded red horizon that has acted as a detachment zone is indicated by a yellow arrow; (b) detailed view of this detachment zone.

A particular cluster of very large boulders and an accumulation of smaller ones lies in a heavily eroded area (area 2a), the only part of the study area at a low elevation between 0.33 and $1.16 \mathrm{~m}$ (Figures 5 and 7). At this site, we consider that the origin of the boulders is associated with the collapse 
of the landward part of the rocky platform (Figure 11), and do not owe their current location to a high energy event. Therefore, these 12 boulders were not considered in the application of hydrodynamic equations.

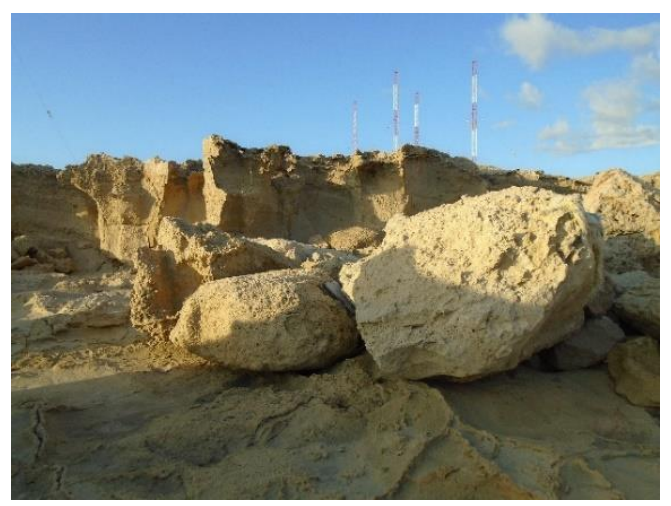

Figure 11. The boulders owe their dislocation to the collapse of the landward part of the rocky platform, which is visible in the back.

At the western part of the study area (area 3) (Figure 12), the dislocated boulders may have a mixed origin, some dislocated from the submarine environment, supporting a submerged scenario while others may have been part of a roof notch collapsed into the sea that were dislocated on the rocky platform during the high energy event(s).

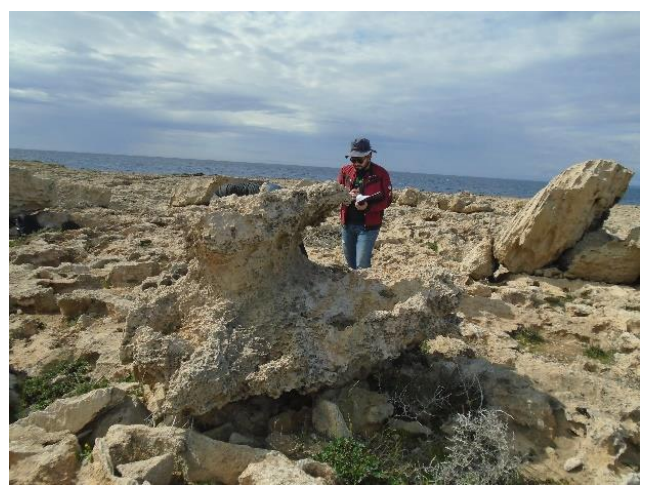

(a)

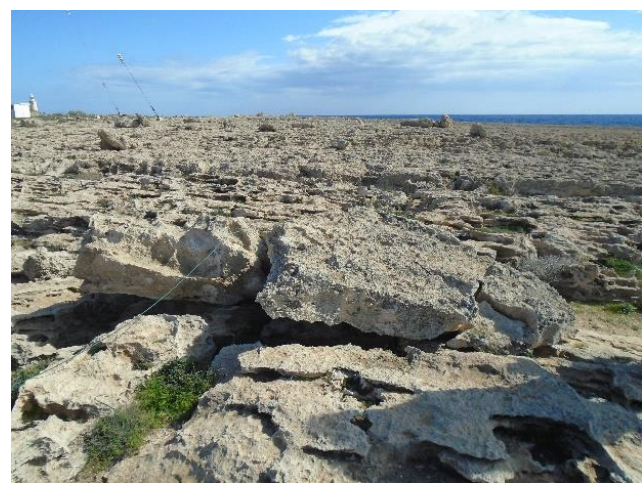

(c)

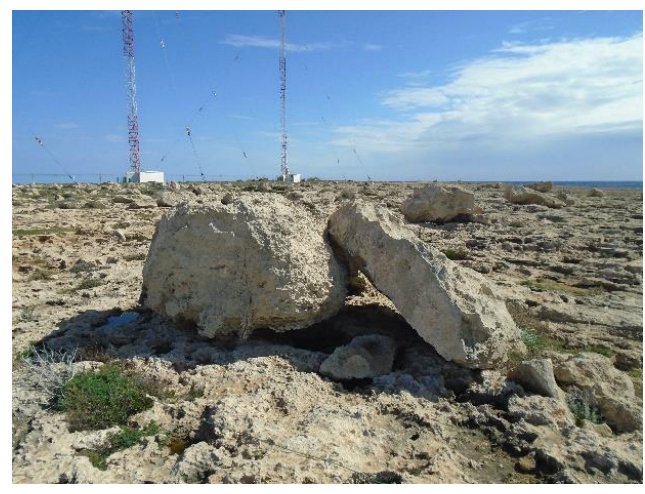

(b)

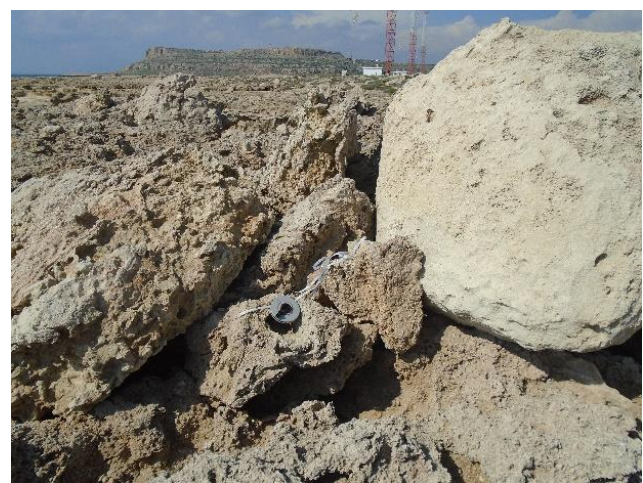

(d)

Figure 12. Boulder deposits on the western part of the study area most likely have a mixed origin; (a) boulder with likely origin from the cliff edge; (b), (c) clusters of boulders; (d) a cluster of boulders of different sizes, the measuring tape provides the scale. 


\subsection{Storm or Tsunami Origin of Deposits?}

It has been noted by several researchers, that the computed volumes may be overestimated, because the shape of the boulders is not a perfect Cuboid [20,24,52]. According to Hoffmeister et al. [53] and Hoffmann et al. [8] boulder volume can be exaggerated even by $30-50 \%$, leading to an overestimation by $28-83 \%$ on the calculated wave heights. Shah-Hosseini et al. [54] reduced the calculated volume by $25 \%$, in order to reduce potential overestimation to boulders with irregular/prismatic shapes. For the calculation of the boulders volume we considered the potential overestimations based on the boulders shape and irregularities and considered $75 \%$ of the total calculated volume.

Two main scenarios were considered, joint-bounded block and submerged boulder, based on the geomorphological evidence of the study area. For the JBB scenario we used the equations of Pignatelli et al. [22] and Nandasena et al. [48], while for the SMB scenario the equations of Barbano et al. [49] and Nandasena et al. [48]. Barbano et al. [49] equations were based on Pignatelli et al. [22] and provided equations for the $\mathrm{SMB}$ and $\mathrm{SAB}$ scenarios.

According to the results of the JBB scenario for the eastern part of the study area (areas 1 and $2 \mathrm{~b})$, a vast majority of the boulders $(\approx 60 \%)$ would require a storm wave higher than $5 \mathrm{~m}$ to trigger their transportation. In fact, wave height calculations indicate storm waves ranging from $5 \mathrm{~m}$ to values higher than $15 \mathrm{~m}$. Such values are significantly higher than those suggested from records of the significant wave height of our study area for the periods 1961-1980 [44], and July 2005-February 2008 [45], where the highest values reaches $4.7-5 \mathrm{~m}$, with a modelled return period of 100 years [44]. On the other hand, in a case of a tsunami, it would require a $4.4 \mathrm{~m}$ height in order to flip a $41 \mathrm{~m}^{3}$ rhombohedric boulder. Thus, the possibility of a tsunami impact is highly possible.

Area 1 hosts many lines of evidence of a tsunami impact. The high-density boulder clusters are oriented perpendicularly (a-axis) to the coast while most are near the detachment zone (see above). Approximately $60 \%$ of the boulders of this area would need storm waves greater than $5 \mathrm{~m}$ for their dislocation, i.e., values between 5 and $11.2 \mathrm{~m}$, values that far exceed the possible storm wave height of the area.

Area $2 b$ further supports the possibility of a tsunami event. According to the results of JBB scenario, only a tsunami could have dislocated the majority of boulders from their original place and lift them on the coastal slope. In case of a storm, $57.1 \%$ of the boulders would require wave height between 5.7 and $17.93 \mathrm{~m}$, for their dislocation, a value incompatible with the available wave records.

On area 3, according to the SMB scenario, $7 \%$ of the boulders would require storm wave heights of 5.3-7.40 $\mathrm{m}$ to be dislocated to their present location. Taking into account the available data of the significant wave heights of the Levantine Sea $[44,45,55]$, there could be a possibility, although rare for the Mediterranean wave regime, for a storm to move submerged boulders and roll them up to the rocky coast slope. In the case of the JBB scenario $60 \%$ of the boulders would require a storm wave height greater than $5 \mathrm{~m}$, with values reaching $15 \mathrm{~m}$.

\subsection{Correlation with Known Tsunami Events}

A number of earthquake and tsunami catalogs exist in the literature for the Mediterranean region [25,26,36,40]. According to Fokaefs and Papadopoulos [25], considering tsunamigenic sources within the Levantine sea, the strongest tsunamis to have stricken the coasts of the Levantine Sea are those of 551 AD, 749 AD, 1068 AD, 1202 AD, 1546 AD, and 1759 AD, while on Cyprus they distinguish in $1222 \mathrm{AD}$ a moderate-strong tsunami (Figure 13). Another known well documented earthquake and tsunami is that of $1303 \mathrm{AD}$, which was generated near the east coast of Crete and affected a large area of the eastern Mediterranean [56].

According to our radiocarbon results, at least two high energy events appear to have impacted the study area. The age from sample LTL19210A appears to broadly correlate with the 1303 AD tsunami that has displaced at least part of the studied boulders. The $1303 \mathrm{AD}$ event is amongst the largest earthquakes in the Mediterranean $(\mathrm{M} \sim 8.0)$, with its epicenter near the eastern coasts of Crete Island [26]. The earthquake brought about severe damage in many locations, such as Crete, 
Rhodes Island, Palestine, Damascus, Cairo, and was felt even in Constantinople and, possibly, in Venice [36]. The generated tsunami was amongst the largest in the Mediterranean, and struck many coastal areas, such as Heraklion in Crete where "... The sea rushed upon the city with such an impetus that many buildings collapsed and many people were drowned ... " [57], Rhodes, Cyprus, Alexandria in Egypt, Palestine, Lebanon, Antalya, and even reached the Adriatic sea [36,43,58]. Tsunami simulations of the historical tsunami of 1303 AD performed by Yolsal et al. [43] has shown that it had affected the Cyprus-Levantine and the Nile Delta regions.

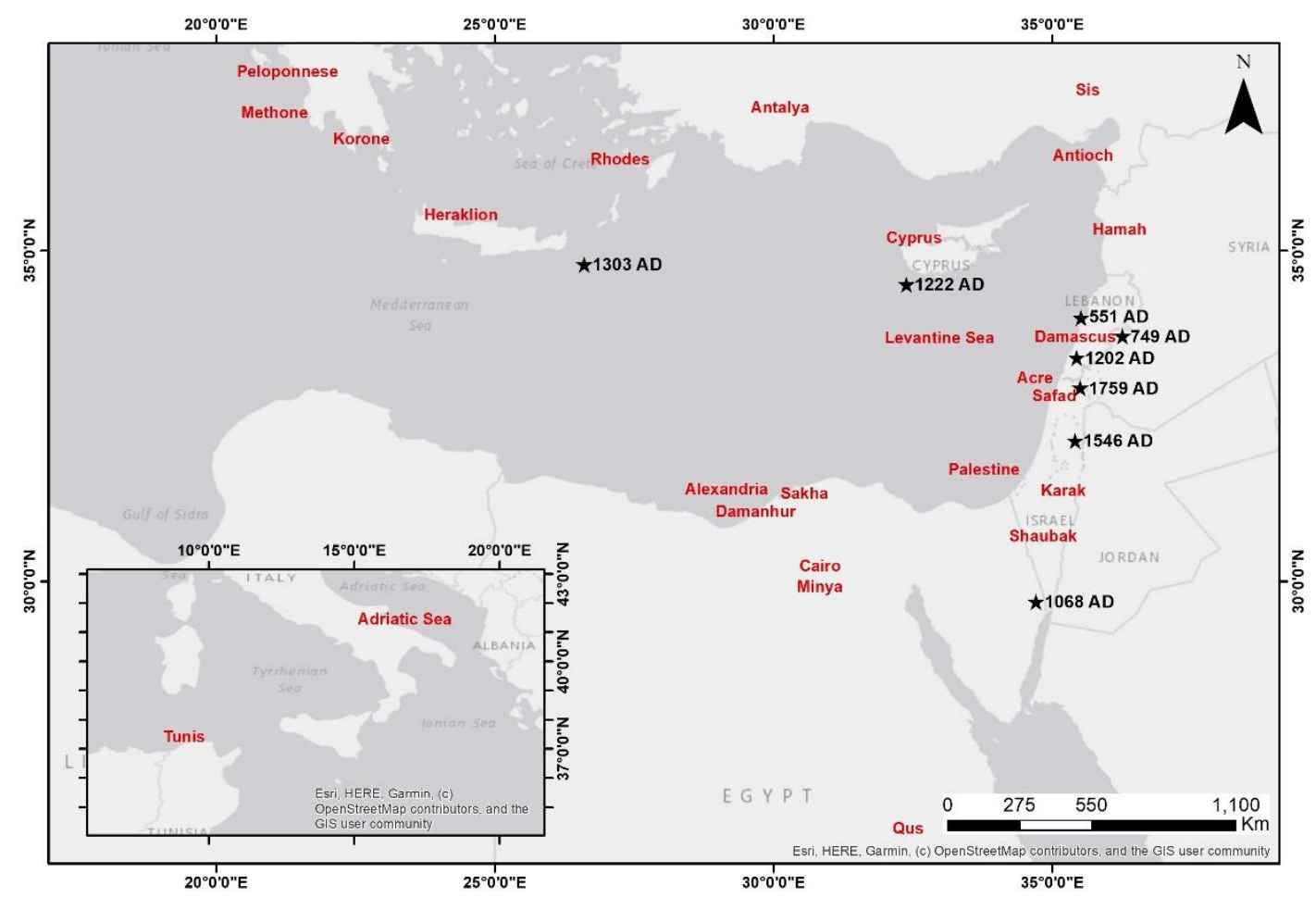

Figure 13. Location of the earthquakes cited in the text (black stars) and sites affected by the 1303 earthquake and tsunami (in red) (from $[36,43,58]$ ).

Another event has been dated at 1512-1824 AD, which does not appear to correlate with a well-known earthquake and associated tsunami. Considering the large number of boulders and sizes in our study area, it is highly likely that they owed their dislocation to multiple events from various sources.

\section{Conclusions}

In this paper we analyzed 272 boulders located at Cape Greco, at the southeastern coast of Cyprus. These boulders are located on a rocky platform of Pleistocene calcarenite, at elevations between 0.33 and $4.5 \mathrm{~m}$ above sea level. Their size, distribution, and geomorphic characteristics suggests that at least some of the studied boulders are due to a tsunami event. The application of hydrodynamic equations to calculate the minimum storm wave height necessary to dislocate these boulders further supports that some of the boulders were transported by a tsunami event. Radiocarbon dating suggests that at least two high energy events have impacted the study area, one associated with the $1303 \mathrm{AD}$ earthquake and tsunami and the second unrelated to any well-known associated tsunami, based on historical sources. Given the large number and variety of sizes in the studied boulders of Cape Greco, it is highly likely that they owed their dislocation to multiple events from various sources.

Supplementary Materials: The following are available online at http://www.mdpi.com/2077-1312/8/10/812/s1, Table S1: Boulder measurements and wave height calculations for all the studied boulders. 
Author Contributions: Conceptualization N.E.; methodology N.E., C.Z., C.S., C.R., A.K., M.P., G.S.; investigation N.E., A.K., M.P., G.S.; writing-original draft preparation N.E., A.K., M.P., G.S.; writing-review and editing C.Z., C.S., C.R. All authors have read and agreed to the published version of the manuscript.

Funding: This research was funded by MARIOLOPOULOS-KANAGINIS FOUNDATION.

Acknowledgments: The authors would like to thank Mariolopoulos-Kanaginis Foundation for funding and supporting the activities of this research. We also thank three anonymous reviewers whose comments improved an earlier version of this manuscript.

Conflicts of Interest: The authors declare no conflict of interest.

\section{References}

1. Goto, K.; Okada, K.; Imamura, F. Characteristics and hydrodynamics of boulders transported by storm waves at Kudaka Island, Japan. Mar. Geol. 2009, 262, 14-24. [CrossRef]

2. Etienne, S.; Paris, R. Boulder accumulations related to storms on the south coast of the Reykjanes Peninsula (Iceland). Geomorphology 2010, 114, 55-70. [CrossRef]

3. Piscitelli, A.; Milella, M.; Hippolyte, J.-C.; Shah-Hosseini, M.; Morhange, C.; Mastronuzzi, G. Numerical approach to the study of coastal boulders: The case of Martigues, Marseille, France. Quat. Int. 2017, 439, 52-64. [CrossRef]

4. Cox, R.; Jahn, K.L.; Watkins, O.G.; Cox, P. Extraordinary boulder transport by storm waves (west of Ireland, winter 2013-2014), and criteria for analysing coastal boulder deposits. Earth-Sci. Rev. 2018, 177, 623-636. [CrossRef]

5. Mastronuzzi, G.; Pignatelli, C.; Sansò, P.; Selleri, G. Boulder accumulations produced by the 20th of February, 1743 tsunami along the coast of southeastern Salento (Apulia region, Italy). Mar. Geol. 2007, 242, 191-205. [CrossRef]

6. Scicchitano, G.; Monaco, C.; Tortorici, L. Large boulder deposits by tsunami waves along the Ionian coast of south-eastern Sicily (Italy). Mar. Geol. 2007, 238, 75-91. [CrossRef]

7. Etienne, S.; Buckley, M.; Paris, R.; Nandasena, A.K.; Clark, K.; Strotz, L.; Chagué-Goff, C.; Richmond, B. The use of boulders for characterising past tsunamis: Lessons from the 2004 Indian Ocean and 2009 South Pacific tsunamis. Earth-Sci. Rev. 2011, 107, 76-90. [CrossRef]

8. Hoffmann, G.; Reicherter, K.; Wiatr, T.; Grützner, C.; Rausch, T. Block and boulder accumulations along the coastline between Fins and Sur (Sultanate of Oman): Tsunamigenic remains? Nat. Hazards 2013, 65, 851-873. [CrossRef]

9. Nandasena, N.A.K.; Tanaka, N. Boulder transport by high energy: Numerical model-fitting experimental observations. Ocean Eng. 2013, 57, 163-179. [CrossRef]

10. Mottershead, D.; Bray, M.; Soar, P.; Farres, P.J. Extreme wave events in the central Mediterranean: Geomorphic evidence of tsunami on the Maltese Islands. Z. Geomorphol. 2014, 58, 385-411. [CrossRef]

11. Roig-Munar, F.X.; Rodríguez-Perea, A.; Martín-Prieto, J.A.; Gelabert, B.; Vilaplana, J.M. Tsunami boulders on the rocky coasts of Ibiza and Formentera (Balearic Islands). J. Mar. Sci. Eng. 2019, 7, 327. [CrossRef]

12. Scheffers, A.; Kelletat, D.; Haslett, S.; Scheffers, S.; Browne, T. Coastal boulder deposits in Galway Bay and the Aran Islands, western Ireland. Z. Geomorphol. 2010, 54, 247-279. [CrossRef]

13. Kortekaas, S.; Dawson, A.G. Distinguishing tsunami and storm deposits: An example from Martinhal, SW Portugal. Sediment. Geol. 2007, 200, 208-221. [CrossRef]

14. Morton, R.A.; Gelfenbaum, G.; Jaffe, B.E. Physical criteria for distinguishing sandy tsunami and storm deposits using modern examples. Sediment. Geol. 2007, 200, 184-207. [CrossRef]

15. Goto, K.; Chavanich, S.A.; Imamura, F.; Kunthasap, P.; Matsui, T.; Minoura, K.; Sugawara, D.; Yanagisawa, H. Distribution, origin and transport process of boulders deposited by the 2004 Indian Ocean tsunami at Pakarang Cape, Thailand. Sediment. Geol. 2007, 202, 821-837. [CrossRef]

16. Goto, K.; Chagué-Goff, C.; Goff, J.; Jaffe, B. The future of tsunami research following the 2011 Tohoku-oki event. Sediment. Geol. 2012, 282, 1-13. [CrossRef]

17. Goto, K.; Sugawara, D.; Ikema, S.; Miyagi, T. Sedimentary processes associated with sand and boulder deposits formed by the 2011 Tohoku-oki tsunami at Sabusawa Island, Japan. Sediment. Geol. 2012, 282, 188-198. [CrossRef] 
18. Nandasena, N.A.K.; Tanaka, N.; Sasaki, Y.; Osada, M. Boulder transport by the 2011 Great East Japan tsunami: Comprehensive field observations and whither model predictions? Mar. Geol. 2013, 346, 292-309. [CrossRef]

19. Morton, R.A.; Richmond, B.M.; Jaffe, B.E.; Gelfenbaum, G. Coarse-Clast Ridge Complexes of the Caribbean: A Preliminary Basis for Distinguishing Tsunami and Storm-Wave Origins. J. Sediment. Res. 2008, 78, 624-637. [CrossRef]

20. Boulton, S.J.; Whitworth, M.R.Z. Block and boulder accumulations on the southern coast of Crete (Greece): Evidence for the 365 CE tsunami in the Eastern Mediterranean. In Tsunamis: Geology, Hazards and Risks; Chapman, N.A., Tappin, D.R., Wallis, S.R., Eds.; The Geological Society of London: London, UK, 2017.

21. Nott, J. Waves, coastal boulder deposits and the importance of the pre-transport setting. Earth Planet. Sci. Lett. 2003, 210, 269-276. [CrossRef]

22. Pignatelli, C.; Sansò, P.; Mastronuzzi, G. Evaluation of tsunami flooding using geomorphologic evidence. Mar. Geol. 2009, 260, 6-18. [CrossRef]

23. Benner, R.; Browne, T.; Bruckner, H.; Kelletat, D.; Scheffers, A. Boulder Transport by Waves: Progress in Physical Modelling. Z. Geomorphol. 2010, 54, 127-146. [CrossRef]

24. Engel, M.; May, S.M. Bonaire's boulder fields revisited: Evidence for Holocene tsunami impact on the Leeward Antilles. Quat. Sci. Rev. 2012, 54, 126-141. [CrossRef]

25. Fokaefs, A.; Papadopoulos, G.A. Tsunami hazard in the Eastern Mediterranean: Strong earthquakes and tsunamis in Cyprus and the Levantine Sea. Nat. Hazards 2007, 40, 503-526. [CrossRef]

26. Ambraseys, N.N.; Synolakis, C. Tsunami Catalogs for the Eastern Mediterranean, Revisited. J. Earthq. Eng. 2010, 14, 309-330. [CrossRef]

27. Kelletat, D.; Schellmann, G. Tsunamis on Cyprus: Field evidences and 14C dating results. Z. Geomorphol. 2002, 46, 19-34. [CrossRef]

28. Whelan, F.; Kelletat, D. Geomorphic evidence and relative and absolute dating results for tsunami events on Cyprus. Sci. Tsunami Hazards 2002, 20, 3-18.

29. Noller, J.S.; Zomeni, Z.; Panayides, I. Preliminary field and GIS-based assessment of tsunami hazard on Cyprus. CIESM Workshop Monogr. 2011, 42, 49-58.

30. Vita-Finzi, C. Evaluating Late Quaternary uplift in Greece and Cyprus. Geol. Soc. Spec. Publ. 1993, 76, 417-424. [CrossRef]

31. Alves, T.M.; Kokinou, E.; Zodiatis, G.; Lardner, R. Hindcast, GIS and susceptibility modelling to assist oil spill clean-up and mitigation on the southern coast of Cyprus (Eastern Mediterranean). Deep. Res. Part II Top. Stud. Oceanogr. 2016, 133, 159-175. [CrossRef]

32. Eaton, S.; Robertson, A. The Miocene Pakhna Formation, southern Cyprus and its relationship to the Neogene tectonic evolution of the Eastern Mediterranean. Sediment. Geol. 1993, 86, 273-296. [CrossRef]

33. Ambraseys, N.N.; Adams, R.D. Seismicity of the Cyprus region. Terra Nov. 1993, 5, 85-94. [CrossRef]

34. Ambraseys, N.N.; Melville, C.P.; Adams, R.D. The Seismicity of Egypt, Arabia and the Red Sea; Cambridge University Press: Cambridge, UK, 1994.

35. Amiran, D.H.K.; Arieh, E.; Turcotte, T. Earthquakes in Israel and Adjacent Areas: Macroseismic Observations since 100 B.C.E. Isr. Explor. J. 1994, 44, 260-305.

36. Soloviev, S.L.; Solovieva, O.N. Tsunamis in the Mediterranean Sea 2000 B.C.-2000 A.D.; Springer: Dordrecht, The Netherlands, 2000.

37. Soren, D. University of Arizona excavations at Kourion, Cyprus. Am. J. Archaeol. 1988, 92, 265.

38. Christou, D. Kourion. Its Monuments and Local Museum; Filokipros: Nicosia, Cyprus, 1996.

39. Evagelatou-Notara, F. Earthquakes in Byzantium from 13th to 15th Century-A Historical Examination; Parousia: Athens, Greece, 1993; ISBN 960-852025-8.

40. Guidoboni, E.; Comastri, A.; Traina, A.G. Catalogue of Ancient Earthquakes in the Mediterranean Area up to 10th Century; Istituto Nazionale di Geofisica: Rome, Italy, 1994.

41. Noller, J.; Panayides, I.; Zomeni, Z. Report on the Preliminary Assessment of Tsunami Hazard in Cyprus; Geological Survey Department: Lefkosia, Cyprus, 2005.

42. Ambraseys, N.N.; Melville, C.P. An analysis of the Eastern Mediterranean Earthquake of 20 May 1202. In Historical Seismograms and Earthquakes of the World; Lee, W.H.K., Meyers, H., Shimazaki, K., Eds.; Academic Press: London, UK, 1988; pp. 181-200.

43. Yolsal, S.; Taymaz, T.; Yalçiner, A.C. Understanding tsunamis, potential source regions and tsunami-prone mechanisms in the Eastern Mediterranean. Geol. Soc. Lond. Spec. Publ. 2007, 291, 201-230. [CrossRef] 
44. Loizidou, X.I.; Dekker, J. Nearshore Wave Climate Analysis for Cyprus, Nicosia, Cyprus; Internal Report; Ministry of Transport, Communication and Work, Department of Public Works: Nicosia, Cyprus, 1994.

45. Ministry of Commerce. Strategic Environmental Assessment (SEA) Concerning Hydrocarbon Activities within the Exclusive Economic Zone of the Republic of Cyprus; Ministry of Commerce, Industry and Tourism of the Republic of Cyprus: Nicosia, Cyprus, 2008.

46. Stuiver, M.; Reimer, P.J.; Reimer, R.W. CALIB 7.1 [WWW Program]. Available online: http://calib.org (accessed on 9 August 2020).

47. Reimer, P.J.; McCormac, F.G. Marine radiocarbon reservoir corrections for the Mediterranean and Aegean Seas. Radiocarbon 2002, 44, 159-166. [CrossRef]

48. Nandasena, N.A.K.; Paris, R.; Tanaka, N. Reassessment of hydrodynamic equations: Minimum flow velocity to initiate boulder transport by high energy events (storms, tsunamis). Mar. Geol. 2011, 281, 70-84. [CrossRef]

49. Barbano, M.S.; Pirrotta, C.; Gerardi, F. Large boulders along the south-eastern Ionian coast of Sicily: Storm or tsunami deposits? Mar. Geol. 2010, 275, 140-154. [CrossRef]

50. Helley, E.J. Field Measurement of the Initiation of Large Bed Particle Motion in Blue Creek Near Klamath, California; USGS Professional Paper 562; United States Government Printing Office: Washington, DC, USA, 1969; pp. 1-19. [CrossRef]

51. Noormets, R.; Crook, K.A.W.; Felton, E.A. Sedimentology of rocky shorelines: 3. Hydrodynamics ofmegaclast emplacement and transport on a shore platform, Oahu, Hawaii. Sediment. Geol. 2004, 172, 41-65. [CrossRef]

52. Spiske, M.; Böröcz, Z.; Bahlburg, H. The role of porosity in discriminating between tsunami and hurricane emplacement of boulders-A case study from the Lesser Antilles, southern Caribbean. Earth Planet. Sci. Lett. 2008, 268, 384-396. [CrossRef]

53. Hoffmeister, D.; Tilly, N.; Curdt, C.; Aasen, H.; Ntageretzis, K.; Hadler, H.; Willershäuser, T.; Vött, A.; Bareth, G. Terrestrial Laser Scanning for Coastal Geomorphologic Research in Western Greece. ISPRS-Int. Arch. Photogramm. Remote Sens. Spat. Inf. Sci. 2012, XXXIX-B5, 511-516. [CrossRef]

54. Shah-Hosseini, M.; Saleem, A.; Mahmoud, A.M.A.; Morhange, C. Coastal boulder deposits attesting to large wave impacts on the Mediterranean coast of Egypt. Nat. Hazards 2016, 83, 849-865. [CrossRef]

55. Galanis, G.; Hayes, D.; Zodiatis, G.; Chu, P.C.; Kuo, Y.-H.; Kallos, G. Wave height characteristics in the Mediterranean Sea by means of numerical modeling, satellite data, statistical and geometrical techniques. Mar. Geophys. Res. 2012, 33, 1-15. [CrossRef]

56. Ambraseys, N. Earthquakes in the Eastern Mediterranean and the Middle East; Cambridge University Press: New York, NY, USA, 2009; ISBN 9780521872928.

57. Antonopoulos, J.A. Data from investigation on seismic Sea waves events in the Eastern Mediterranean from 1000 to 1500 A.D. Ann. Geofis. 1980, 19, 141-248.

58. Guidoboni, E.; Comastri, A. The large earthquake of 8 August 1303 in Crete: Seismic scenario and tsunami in the Mediterranean area. J. Seismol. 1997, 1, 55-72. [CrossRef]

Publisher's Note: MDPI stays neutral with regard to jurisdictional claims in published maps and institutional affiliations.

(C) 2020 by the authors. Licensee MDPI, Basel, Switzerland. This article is an open access article distributed under the terms and conditions of the Creative Commons Attribution (CC BY) license (http://creativecommons.org/licenses/by/4.0/). 